\title{
Article
}

\section{Doing the plastic fantastic: 'artificial' adventure and older adult climbers}

Hickman, Mark Timothy, Stokes, P, Beard, C and Inkster, Allison Available at http://clok.uclan.ac.uk/18798/

Hickman, Mark Timothy, Stokes, P, Beard, C and Inkster, Allison ORCID: 00000002-7345-7015 (2019) Doing the plastic fantastic: 'artificial' adventure and older adult climbers. Journal of Adventure Education and Outdoor Learning, 19 (2). pp. 172-182. ISSN 1472-9679

It is advisable to refer to the publisher's version if you intend to cite from the work. http://dx.doi.org/10.1080/14729679.2017.1308874

For more information about UCLan's research in this area go to http://www.uclan.ac.uk/researchgroups/ and search for <name of research Group>.

For information about Research generally at UCLan please go to http://www.uclan.ac.uk/research/

All outputs in CLoK are protected by Intellectual Property Rights law, including Copyright law. Copyright, IPR and Moral Rights for the works on this site are retained by the individual authors and/or other copyright owners. Terms and conditions for use of this material are defined in the policies page.

\section{CLoK}

Central Lancashire online Knowledge www.clok.uclan.ac.uk

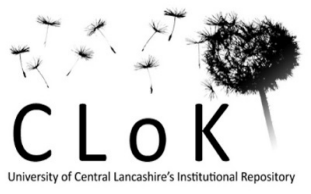




\title{
Doing the plastic fantastic: 'artificial' adventure and older adult climbers.
}

\author{
Mark Hickman, Peter Stokes, Colin Beard \& Allison Inkster (Sharon \\ Rosser?).
}

\begin{abstract}
.
The aim of this paper is to determine the perceptions and experiences of climbing at artificial climbing walls (ACWs) as undertaken by a cohort of 'youngold' people (circa 65-75). The engagement of older people in outdoor activities and adventure is an evolving topic, however, as part of this development little has been written on the use of ACWs. Methodologically, the research employed in-depth semi-structured focus groups and interviews with a purposive convenience sample of six, subsequently expanded to ten through snowball technique. Male and female sexes were equally represented. Manual thematic analysis identified two key motifs: ACWs and the notion of adventure; and, ACWs and the potential for learning. The findings point at: what constitutes 'real' adventure for this group of older adults; the shifting nature of 'old age'; the significance of self-awareness; and the role of reflexivity and physical activity in the construction of a 'successful' old age.
\end{abstract}

Key words: adventure, artificial, climbing, learning, older adults.

\section{Introduction.}

This paper examines the perspectives and experiences of older-adults in relation to artificial climbing walls. The study therefore interfaces domains exhibiting contested definitions: ageing - and in particular 'older age', and, the nature of, and relationship of 'outdoors' and adventure.

The growing proportion of the population which is 'becoming old' is an issue in many developed economies. The Office for National Statistics (2016) estimates that there are over 11 million people aged over 65 in the United Kingdom (UK). This number is predicted to rise to 16 million over the next two decades, and by 2040 nearly one-quarter of people in the UK will be 65 or over (Office for National Statistics, 2015). However, when older adult life 'begins' and is gauged remains contested and there are differing perceptions of what 'to age' means (Boksberger \& Laesser, 2009; Westerhof \& Tulle, 2014). For example, Age UK (2016) found that many 60-69 year olds disagree over whether these years should be termed 'middle' or 'later' life. This tension is reflected in scholarly literature where there exists little consensus on age across diverse fields encompassing, for instance: sociology (Dannefer \& Settersten, 2013) demographics (Victor, 2013), psychology (Marcoen, Coleman \& O'Hanlon, 2014) or biology (Westendorp \& Kirkwood, 2014). The age of retirement (sic: exiting the workforce) - generally at 60-67 years old in developed economies - is a key indicator of older age. (Organization for Economic Cooperation and Development, 2014). Nevertheless, Levine (2008) argues that any metric by which individuals are deemed 'old' is subjective. Nutrition, education, healthcare, 
lifestyle and working conditions can lead to wide variations between chronological (i.e. from date of birth) and biological (i.e. current physical condition) and indeed psychological 'ages'. Thus, viewing ageing as simply a linear process appears simplistic and it is perhaps more appropriate to: "understand aging as a lifelong experience that is multifaceted and shaped by the contexts in which individuals live" (Moody \& Sasser, 2015: 2). As in other domains, within outdoor adventure, it is difficult to find a consensus in relation to older adulthood. Brennan's (2008) work, on older adults conducting a rafted descent of the River Colorado suggested three distinct phases to older adulthood: young-old, from 65-74; old-old, from 75-84; and, oldest-old, from 85+. This seems a useful and insightful scale and tallies with broad understanding in the field and therefore is the classification employed in this paper. There has been a growing body of research on the older adults and the outdoors (Brennan, 2008; Hickman et al, 2016; Humberstone, 2016). However, hitherto, little has been written on the use by older adults of artificial climbing walls (AWCs) which nevertheless represent a prevalent form of entertainment per se and outdoor preparation. The paper now turns to consider this issue.

\section{Re-imagining adventure for the older adult: preamble to use of AWCs.}

Concerns for the UK nation's health (Kiran \& Pinto, 2016; Lee, 2015; Steptoe, Deaton \& Stone, 2015) have seen the outdoors promoted as a public health resource (Ashton, 2014; Council for Learning Outside the Classroom, 2014; Fenton \& Hamblin, 2016). As indicated, the marriage of adventure sports with older adults is nascent and, within this domain, non-traditional urban and artificial adventure settings have received relatively little attention. Paradoxically, this occurs at a time of unprecedented growth in artificial climbing wall activity in the UK, with five million people registering visits on an annual basis (Sport England, 2014).

To better understand older adult behavior in relation to AWCs, it is important to appreciate older adulthood perspectives in relation to broader outdoor contexts. Humberstone (2016: 197) suggests, physical activity can help older adults 'learn to be in the body', while other observers underline positive management of appearance, identity, well-being, and commitment to activity (Jankowski et al., 2016; Oliver, Hudson \& Thomas, 2016; Strachan et al., 2010). Such work offers insight into older adult experience and what prompts continued involvement. Whilst research pragmatically recognizes older people as being susceptible to poor health at some point (Office for National Statistics, 2013; Stuart-Hamilton, 2011) it also highlights the benefits of their participation in regular physical activity (Cutler-Riddick, 2016; National Institute on Ageing, 2014; Wolinsky, Weg, Howren, Jones \& Dotson, 2013). Vitally, however, the focus is leaning towards physical activity being meaningful enough to add quality to life (McBarnett, 2016: 23) and to contribute to functional health and well-being (Chodzko-Zajko, Schwingel \& Park, 2009) rather simply considering its physical aspect. Rather than steering individuals towards traditional patterns of healththrough-fitness, Howes (2016) suggests that adventurous approaches to physical 
activity have significant, and largely uncharted, potential for developing intrinsic focus and the prioritization of internal benefits, such as self-control, mastery, flow and self-paced achievement. Notions of 'serious leisure' (Davidson \& Stebbins, 2011; Stebbins, 2002; Stebbins, 2014) and savoring (Bryant \& Veroff, 2007; Hickman, Inkster, \& Rosser, 2016; Hickman, Stokes, Gammon, Beard \& Inkster, 2016) add weight to the argument that adventure sports and growing older can co-exist positively. A range of theoretical underpinnings lends credibility to this idea. Evidence suggests that that the higher the social component of serious leisure the more likely that committed and regular engagement will occur (Lee \& Payne, 2015). Boyes (2013) develops these views further by suggesting it is the social capital associated with belonging to a community with strong social ties that underpins the benefits of adventure for older people. Apart from the physical activity itself, he points to the interaction, social support and shared experiences that form a nucleus of benefits, which include, but are not necessarily limited to, good will, fellowship and social connection to both people and familiar places (Brymer, Downey \& Gray, 2009; Wood \& Giles-Corti, 2008). The compelling need for climbers to work with partners reinforces this (Hansen, 2013), as does the highly interactive potential of ACWs (Atchinson-Jones, 2004; Hill, 2009).

\section{Artificiality and AWCs: shifting notions of adventure.}

The history of climbing is complex and variously characterized by exploration, empire, nationalism, determination, and resilience. This has generated a rich literature, characterized by imperial superiority, modesty, understatement, egotism and recrimination and has engendered public debates on what constitutes climbing and true adventure and what they should be. (Isserman, 2008; Wade, 2012). Historically, for example, Paul Preuss, an Austrian born in 1886, declaimed the use of 'artificial climbing aids' in which he included guides and even a rope (Messner, 2011) stating that they rendered the activity mechanistic. Moreover, Bruce's 1922 British attempt on Everest was riven by a potent disagreement over whether or not to use artificial oxygen. Mallory considered this, together with the use of eiderdown clothing - both now in common use in high altitude mountaineering - as 'unsporting' (Wainwright, 2016). More recently, the rejection of all artificial aid for 'traditional' climbing can be seen in climbers such as Alex Honnold who scales huge cliffs with little more than modern rock shoes for assistance (Honnold, 2015). Donnelly (2003) suggests the debate amongst climbers, over what both 'adventure' and 'climbing' might be, reflects their non-conformist and rebellious nature, something likely to continue as the mainstays of ACW activity have been added to the roster for the 2020 Olympic Games in Tokyo (Burnside, 2016).

Whether, and how, ACWs constitute adventure is also subject to debate. Many practitioners might argue that any bolted, or 'sport' climbing, where routes are pre-prepared, as at ACWs, devalues the experience of adventure, and dilutes the 'purity' of climbing, whereas Robinson (2008: 3) celebrates climbers' ability to adapt to new spaces as reflecting their "spatially fluid" nature. Additionally, she questions the presumption that it is the centrality of 'risk' that lends itself to 
climbers, and other adventure sports groupings, which are so closely-knit and inter-connected. Beames and Varley (2013: 77) underline that adventurous recreation is undergoing rapid change with 'adventure cathedrals' for snow sports enthusiasts, white water kayak and surf courses, providing integrated experiences where people can access artificial environments, buy meals, clothes and accessories in addition to seeking adventure. Many ACWs too offer this type of integrated environment with cafés and shops offering patrons not only the opportunity to climb but also to access courses, watch films, attend lectures and presentations, host special occasion parties and act as a gateway to other activities too.

\section{Methodology.}

With the growth of older adult related studies (British Society of Gerontology, 2015) there has been a parallel development in research methods (particularly qualitative) available to scholars (Sparkes \& Smith, 2014). In spite of this work, there is still a limited understanding of the variegation of growing older (Victor, Westerhof \& Bond, 2014). Moreover, there is further scope to use methods which enhance the older adult voice as one that is liberating and positive. Thus, the older adults involved with this study were encouraged to be active participants, rather than passive recipients of the research process (Hubble \& Tew, 2013). Using a critical friend as checker (Selkrig \& Keamy, 2015) brought rigour to the decision-making process, important as the investigators were all climbers and accepted as insiders with the attendant risks of habituated assumption and critical disability (Tajfel, 2010; Costley, Elliott \& Gibbs, 2010; Greenleaf, 2002). The research used a convenience purposive sample of six based at a climbing wall in north-west England. This was expanded to ten by snowballing, a technique useful to identify hard-to-reach populations (Dusek, Yurova \& Ruppel, 2015). There was an equal split between females and males, and although the majority of the sample was aged between 65 (Tony and Frank) and 72 (Sadie), placing them within the young-old category, there was one outlier aged 82 (Jack).

We adopted British Mountaineering Council (BMC) guidelines that an 'experienced' indoor climber should have the techniques and skills to be able to lead and belay confidently at grade F6a (Mountain Leader Training, 2009). Whilst all participants could climb at this grade the range of experience within the sample was considerable with Tony having started climbing in his teens, Mandy in her late thirties, and her climbing partner, Lizzie, whilst a sixth former. Tony was the only person to hold formal climbing qualifications (Single Pitch Supervisors Award (SPSA)), and Mandy and Lizzie held the Mountain Instructors' Award (MIA) and Mountain Instructors' Certificate (MIC) respectively, both high-level professional qualifications denoting significant skill and experience.

Data collection commenced with a semi-structured focus group followed by six targeted 20-minute semi-structured interviews carried out by a researcher at an ACW for reasons of practicality and familiarity. Using thematic analysis two 
researchers analyzed the data, designated initial codes and then identified lower and higher order themes (Braun \& Clarke, 2013; Howitt, 2010). The critical friend offered advice throughout this process.

\section{Discussion.}

The two emergent themes for consideration in this paper were:

1. Artificial climbing walls and adventure.

2. ACW, adventure and learning.

\section{Artificial climbing walls and adventure.}

Following a career as a professional outdoor educator and performance white water kayaker, with many notable first descents to his credit, Frank (65) was a self-confessed 'returner to climbing' after a decade away. He felt the suggestion by some climbers that ACWs made adventure redundant was nonsense:

'Is an [outdoor] climber top-roping something that pushes and thrills him [or her] as an adventurer? Hell YES!!! They've got no more chance of coming to any real harm, sort of, but I'm sure we've both seen people so at their limits [...] at walls that they get crag fast [stuck] and unable to move.'

Newly retired, Frank's re-engagement with climbing at ACWs reflected elements of innovation (Nimrod, 2016), partly due to his ten years' absence. His prior climbing was also 'traditional': thus, the ACW was a new experience. He continued:

'And me? I'm an HVS 5 a man, maybe $5 \mathrm{~b}$ on a good day with a following wind: Flying Buttress on the Cromlech. But as for leading indoors? Do you know what a sloper is? Well when I'm on the sharp end of one of those, eight or nine clips up and I'm flagging, ask me 'how's it going with the old comfort zone right now?'

Although Nimrod (2016) acknowledges some shortcomings with work in innovation theory she also points to findings that firmly highlight well-being. Additionally, Nimrod and Rotem (2012) show that innovations focusing on internal and intrapersonal processes lead to high levels of satisfaction, something Frank seems to experience at the ACW:

'[N]ow I'm retired [...] I potentially live in the world's capital of comfort zones. Are you with me if I say 'Get me the [...] outta here? And that's just what I can do at the wall - get adventures right out of my comfort zone [...] what I can tell you is that the adventures that I am having at the climbing wall make me feel like I've had a good day.'

'Bones' offered a similar perspective: 
' $[\mathrm{A}]$ ttempting $6 \mathrm{~b}$ on the big wall at Kendal may have zero risk of death and only a tiny risk of injury, but when I'm trying to clip that ninth quickdraw with screaming muscles and quivering calves, I'm light years from comfortable [...] even watching [my climbing partner] attempting the same things proves a severe test of my continence ...' (Bones, 68, male).

Mandy (67), who had gained the Mountain Instructor Award (MIA) in her late 50 s, offered a viewpoint from her work introducing older adults from isolated rural communities to physical activity through climbing at ACWs:

'My [...] experiences with groups of over 60s, all beginners [...] totally confirms that you can't separate adventure [from] artificiality. It's in the mind [...] Climbing would have remained for them in the ranks of looneytune activities and only for crazy people who had an urgent appointment with death. Then they see this large hall, steep walls, multi-coloured composite holds, ropes and padded bouldering areas where everything is an adventure - so very different to what they know. The climbing? Well, for most if not all the 'most adventurous and out-there' thing most of them had ever done. You'd have a job convincing them they weren't adventurers now!'

Here, Mandy touches on Beams and Varley's (2013) concept of the ACW as a 'cathedral of adventure', with the activity and the space surrounding it synergizing the concept of adventure. Her climbing partner Lizzie (69), a recently retired General Practitioner, holding the Mountaineering Instructor Certificate (MIC), continued, emphasized the multi-sensory ACW environment:

'[I]n my experience of climbing with older adult beginners on a wall, there is definitely adventure at work! And you're right, it's not just the climbing, but the sights, the sounds, even the smells of chalk and rope on their hands.'

Like Frank and Bones, her experience did not preclude her from a sense of adventure indoors, reflecting the spatial fluidity and debate over risk suggested by Robinson (2008). Lizzie continued: "I might be aware of the distinction between real and apparent danger, but adventure isn't redundant for me just because it takes place indoors, and it isn't dependent just on danger".

Additionally, such spatial fluidity invites a re-consideration of Iso-Ahola's (1986) 'substitutability' of leisure behaviour exploring the practice of replacing one leisure activity for another. However, rather than substituting the activity, the older adults show a portability of adventure across natural and artificial boundaries. Frank articulated that for him the adventure is in the grade of climb being attempted irrespective of real or artificial rock, saying: "ACWs put me on much more technically challenging routes than [...] in the past". Jack (82), the oldest participant, agreed:

'I still climb outdoors, ice climb, have been up Mera Peak and Pik Lenin, so I'd say I've got a pretty good idea of what adventure is. I use the [ACW] 
mainly in winter and my adventure is in pushing my grade, indoors or out [...] I'm 'having an adventure.'

This supports Stebbins' (2005) research with climbers where adventure was not solely dependent upon natural settings and was closely allied to task. Furthermore, borrowing from the work of Mobily, Lemke and Gisin (1991) it allows us to posit the idea that irrespective of location these older adults appear to have an 'adventure repertoire' based on internal perceptions of meaning and value.

\section{ACW, adventure and learning.}

Like Frank, Tony (65) was a "newly minted pensioner". An ex-PE teacher, he emphasized the link between adventure and learning at artificial sites:

'If we can't have adventures on artificial walls, then places like Holme Pierrepont and Lee Valley for canoeing, the via ferrata in the Lakes, and that new place for surfing in Snowdonia can't count [...] neither can indoor snow domes or outdoor ski slopes that use blowers [snow machines]. Where do we stop? We need to let go of the idea that we can only adventure outside. And when we're having adventures we're learning [and] I'm learning.'

Soo (66), still working in human resources, and active in the Duke of Edinburgh's (DoE) Award, developed this idea: "it's ridiculous to even think that [such places] aren't good for teaching or learning, old or young". She indicated that such selfpaced activity could help older adults learn about appropriate physical activity (Chodzko-Zajko et al., 2009):

'We use adventure in the DoE to teach youngsters about their physicality and potential: climbing, paddling, walking and the like. But nobody thinks we [older adults] need to know how to live in this new old-body. I do: teenager in my head, wrinkles in my skin. I wasn't born 66, and here at [the ACW] I'm constantly surprised what I take for granted, at what my body can do [...] not just what it can't... Why isn't there a DoE to teach us older folks what we might be capable of?'

Dave (67), a former psychologist, also endorsed how ACWs facilitate learning about the older body now inhabited (Humberstone, 2016):

'A climbing wall lends itself well to developing good general technique paying attention to feet, changing body position to aid balance and evolving a sense of 'sequences of moves', not to mention developing arm, finger and core strength [and] learn about balance, accuracy, timing, coordination and strength.'

He went on to point out that the lack of intellectual challenge experienced by many older adults once retired could be offset by climbing: 'making sure they're 
properly tied in and their belayer's awake tends to focus the mind, like Soo said, young or old!....As a psychologist, I definitely believe [that adventure] is highly individual, not geographical'.

Dave also highlighted the social nature of ACWs, and their role in coping with retirement issues such a surfeit of time and potential loss or renewal of identity (Jankowski et al., 2016; Strachan et al., 2010). The day of the focus group was a cheap 'lunchtime special', climbing slot well attended by older adults: 'look at the social space [here at the ACW]' Dave observed, pointing to the wall:

'Do we really think all this lot knew each other through work? I don't think so. Then all of a sudden they're on the [phone] and Facetiming each other to sort out when and who to meet.'

Leafy, 69, had only three years' ACW experience. After a decade's caving activity and her realization that 'I couldn't 'haul gear sacks around like I used to'... 'I just stopped caving. Dead. Like that. [clicking her fingers] I didn't want to be a hanger-on. Somebody who used to cave.' She had turned up at the wall, without a belay partner looking to put a 'wanted' notice up in the reception. "Instead, I got chatting" she said, nodding towards Mandy:

'...and there I was, climbing with somebody who really was a beginner. Just started. That's probably why you put me with [name] wasn't it, to get me involved?'

Sat in the café overlooking the climbing area. Mandy nodded, adding:

'Look down there. On the same panel there's climbs from 4 to $6 \mathrm{a}$, so it's great for beginners and [experienced climbers] to mix and get to know each other. Look at you now [nodding back at Leafy], giving up caving wasn't the end of the world, and you're now, what, a CWA [Climbing Wall Award holder]?'

Laughing, she commented on Leafy's dress code: 'yeah, look at you - all BD jeans and no shoes', all of which had been bought at the shop below the café: 'no more plastic overalls for you then - height of fashion, not!' In essence, Leafy had substituted one set of skills and social networks for another and in the process taken to instructing. For her, the ACW had been the conduit to new teaching skills, a reinvented identity, perhaps even greater independence. Her husband still caved:

'I was worried we'd end up following different lives but we haven't. Funny really, we've probably got just as much, maybe more to talk about. And he comes to my [climbing club] do's and I go to his - see all the old familiar faces.'

Additionally, this invites consideration of the way that, for Leafy, the ACW has been a means of re-casting her identity (McAdams, 1993). Retirement can offer a significant challenge to identity as familiar routines disappear. For several of the 
respondents, adventure sport, articulated through ACWs, offered an alternative lifestyle and identity that of the workplace. But, for Leafy, retiring from work in university finance and leaving caving saw two transitions collide with potentially disastrous consequences for her concept of self and well-being. However, she had managed successfully to substitute one adventurous serious leisure activity for another, embracing the change with no overtly negative effects.

\section{Conclusion.}

This study examined the perceptions and experiences of climbing at ACWs as evidenced by ten 'young-old' people. This was set in relation to the context of concerns over the health and well-being of a generally ageing population and unprecedented growth of ACWs with the prospect of accessible urban adventure. Life after retirement for this cohort appeared less problematic than reported for some older adults, and rather than being a period of identity crisis or reinvention, allowed for the transfer of strong concepts of self-awareness shaped in the adventure environment of climbing. Participants found debates over whether certain types of activity could, or should, be defined as 'adventure' largely redundant. Instead, as articulated by Dave, adventure was in the mind of the beholder rather than limited to a geographical outdoor space: their climbing was 'real' because it was a felt to be so. Furthermore, the ability to experience adventure, indoors or out, reflected their 'spatial fluidity' and adaptability as described by Robinson (2008). Moreover, the study determined that for these older adults, ACWs afforded opportunities for learning. New skills were being developed, new social networks forged, and the potential of the older bodies they now found themselves in established. Contrary to expectations, the new landscape of life after retirement was not perceived as one of limitations but of opportunities to be explored, and assumptions about older adult bodies renegotiated.

The study opens avenues for further research in a number of regards. First, Lavallee and Wylleman (2006) demonstrate that career transitions are times of potential stress and anxiety. A focused consideration of how serious leisure and adventure sports might function to ameliorate this would be useful. Secondly, the first cohort of baby boomers, born between 1946 and 1964, came of age in 2011. This generation enjoyed better access to education and health care than at any previous time. They have also witnessed great shifts in ideas about power and agency. There is further scope to examine how body, embodiment and identity (Ryba, Schinke \& Tenebaum, 2010) are constructed and experienced across a range of adventure sports and in particular how this is experienced by males and females. Thirdly, another important practical implication concerns the training, assessment and continued professional development of adventure sports coaches. Three female respondents in this study held climbing instructing/coaching awards. Lizzie pointed out that when she first qualified with her Single Pitch Supervisors Award (SPSA) climbers were perceived as homogenous. Now superseded by the Single Pitch Award (SPA), for outdoors, and the CWA, for ACW (as held by Leafy) these contemporary syllabuses assume that beginners will be children and young adults. As Lizzie, Leafy and Mandy all observed, new instructors are now expected to know something about 
instructing youngsters yet the ageing population remains invisible. If the debate over the skills needed to be an adventure sports coach is to be progressed, a better understanding of the instructional needs of older adults should be developed.

Finally, the findings from this study offer some encouragement regarding engagement of older adults however social exclusion still exists for many. This investigation reveals some of the ways that one cohort of older adults experienced their adventures at ACWs and also highlights the vital need for more research into the diversity of perceptions about adventure held by older people. As observed by Tony, urban areas play host to many types of 'artificial' adventure resources, yet their potential for use by older adults requires exploration and development before their potential can be optimized.

\section{References.}

Age UK. (2016). Later Life in the United Kingdom: August 2016. Available from: www.ageuk.org.uk/Documents/EN-

GB?Factsheets/Later Life UK factsheet.pdf?dtrk=true (Retrieved $1^{\text {st }}$ October 2016).

Ashton, J. (2014). Outdoor education is a public health issue. Keynote speech at the Institute for Outdoor Learning North-West Conference. Dallam Outdoor Centre. $24^{\text {th }}$ January.

Atchison-Jones, D. (2004). Climbing Dyno-mite: Learning to climb on indoor walls. London: Jingo Wobbly.

Beames, S., \& Varley, P. (2013). Eat, play, shop: The Disneyization of adventure. In Taylor, S., Varely, P., \& Johnston, T. (Eds). Adventure Tourism: Meanings, experience and learning. (77-84). London: Routledge.

Boksberger, P., \& Laesser, C. (2009). Segmentation of the senior travel market by means of travel motivations. Journal of Vacation Marketing. 15 (4), 311-322.

Braun, V., \& Clarke, V. (2013). Successful qualitative research: A practical guide for beginners. London: Sage.

Brennan, D. (2008). Older Adults in Adventure Education: Making Meaning of Older Adults' Inner Experience of Experiential Education. Saarbrücken: VDM Verlag Dr. Muller.

Bryant, F.B., \& Veroff, J. (2007). Savoring: A New Model of Positive Experience. Mahwah, NJ: Erlbaum.

Brymer, E., Downey, G., \& Gray, T. (2009). Extreme sports as a precursor to environmental sustainability. Journal of Sport and Tourism. 14 (2/3), 193-204. 
Burnside, P. (2016). Climbing going for gold. Available from www.thebmc.co.uk/sport-climbing-olympic -games (retrieved 1st November 2016).

Chodzko-Zajko, W., Schwingel, A., \& Park, C.H. (2009). Successful aging: the role of physical activity. American Journal of Lifestyle Medicine. January/February 2028.

Costley, C., Elliott, G., \& Gibbs, P. (2010). Doing Work Based Research: Approaches to Enquiry for Insider-Researchers. London: Sage.

Council for Learning Outside the Classroom. (2014). What role does the outdoor sector play in public health? Available from: www.lotc.org.uk/what-role-doesthe-outdoor-sector-play-in-public-health-what-role-could-it-have/ (Retrieved $19^{\text {th }}$ October 2016).

Cutler-Riddick, C. (2016). The importance of physical activity and recreation to ageing well: Unveiling research findings and take away ideas. In B. Humberstone \& M. Konstantaki (Eds.), Ageing, Physical Activity, Recreation and Wellbeing (121). Newcastle upon Tyne: Cambridge Scholars Publishing.

Davidson, L., \& Stebbins, R.A. (2011). Serious Leisure and Nature: Sustainable Consumption in the Outdoors. London: Palgrave Macmillan.

Donnelly, P. (2003). Sport climbing vs Adventure climbing. In Rinehart, R.E., \& Sydnor, S. (Eds). To the Extreme: Alternative Sports Inside and Out. (291-306). Albany, NY. State University of New York.

Dusek, G.A., Yurova, Y.V., \& Ruppel, C.P. (2015). Using social media and targeted snowball sampling to survey a hard-to-reach population: A case study. International Journal of Doctoral Studies. 10, 279-299. http://ijds.org/Volume10/IJDSv10p279-299Dusek0717.pdf (Retrieved 16th February 2016).

Fenton, K., \& Hamblin P. (2016). Public health is a priority for our National Parks. Available from: https://publichealthmatters.blog.gov.uk/2016/08/08/publichealth-is-a-priority-for-our-national-parks (Retrieved 19th October 2016).

Greenleaf, R.K. (2002). Servant Leadership: A journey into the nature of legitimate power and greatness. New York: Paulist Press.

Hansen, P.H. (2013). The Summits of Modern man: Mountaineering after the Enlightenment. London: Harvard University Press.

Hickman, M., Inkster, I., \& Rosser, S. (2016). Growth in action: Adventure sports and personal learning past the age of 65. Presentation given to the Institute for Outdoor Learning National Conference. Yarnfield Park, Staffordshire. 14-16 th October 2016. 
Hickman, M., Stokes, P., Gammon, S. Beard, C., \& Inkster, A. (2016). Moments like diamonds in space: Savoring the ageing process through positive engagement with adventure sports. Annals of Leisure Research. DOI: 10.1080/11745398.2016.1241151.

Hill, P. (2011). Indoor Climbing: Technical skills for climbing walls for novices, experts and instructors. Singapore: KHL Publishers.

Honnold, A. (2015). Alone on the Wall: Alex Honnold and the Ultimate Limits of Adventure. London: Macmillan.

Howes, M. (2016). Challenging fitness ideology: Why an adventurous approach to physical activity is better for well-being. Sport, Ethics and Philosophy. 10 (2), 132147.

Howitt, D. (2010). Introduction to Qualitative Methods in Psychology. Harlow: Prentice Hall.

Hubble, N., \& Tew, P. (2013). Ageing, Narrative and Identity: New Qualitative Social Research. London: Palgrave Macmillan.

Humberstone, B. (2016). Researching the Active Ageing Body: What Inspires Continued Participation by Men and Women over 60 in Alternative Physical Activities? In B. Humberstone \& M. Konstantaki (Eds.), Ageing, Physical Activity, Recreation and Wellbeing (196-210). Newcastle upon Tyne: Cambridge Scholars Publishing.

Iso-Ahola, S.E. (1986). A theory of substitutability of leisure behavior. Leisure Sciences: An Interdisciplinary Journal. 8 (4), 367-389.

Isserman, I. (2008). Fallen Giants: A History of Himalayan Mountaineering from the Age of Empire to the Age of Extremes. Devon, PA: Duke Publishing.

Jankowski, G.S., Diedrichs, P.C., Williamson, H., Christopher, G., \& Harcourt, D. (2016). Looking age-appropriate while growing old gracefully: A qualitative study of ageing and body image among older adults. Journal of Health Psychology. 21 (4), 550-561.

Katz, S. (2013). Active and successful aging: Lifestyle as a gerontological idea. Recherches sociologiques et anthropologiques. 33-49. Doi: 10.4000/rsa.910. www.rsa.revues.org/910 (Retrieved 4th March 2016).

Katz, S. \& Calasanti, T. (2015). Critical Perspectives on Successful Aging: Does It "Appeal More Than It Illuminates"? The Gerontologist. 42 (6), 725-726.

Kiran, T., \& Pinto, A.D. (2016). Swimming 'upstream' to tackle the social determinants of health. BMJ Quality \& Safety. 25, 138-140. DOI: $10.1136 / \mathrm{bmjqs}-$ 2015-005008. 
Lavallee, D. \& Wylleman, P. (2006). Career Transitions in Sport: International Perspectives. West Virginia: FiT Publishing.

Lee, C., \& Payne, L.L. (2015). Exploring the relationship between different types of serious leisure and successful aging. Activities, Adaptations and Ageing. 39 (1), 1-18.

Lee, G. (2015). Obesity, the epidemic that CAN be stopped? Journal of Advanced Nursing. 71 (9), 1971-1972.

Levine, R. (2008). Ageing with Attitude: Growing Older with Dignity and Vitality. Westport, CT: Prager.

Marcoen, A., Coleman, P.G., \& O’Hanlon, A. (2014). Psychological ageing. In J. Bond., S. Peace., F. Dittmann-Kohli \& G. Westerhof. Ageing in Society. (38-67). London: Sage.

McAdams, D.P. (1993). The Stories We Live By: Personal Myths and the Making of the Self. New York: Guildford Press.

McBarnett, O. (2016). Ageing well: The local perspective. In B. Humberstone \& M. Konstantaki (Eds.), Ageing, Physical Activity, Recreation and Wellbeing (22-42). Newcastle upon Tyne: Cambridge Scholars Publishing.

Messner, R. (2011). The Philosopher of Free Climbing: The Story of Paul Preuss. Washington, DC: National Geographic Paperbacks.

Mobily, K.E., Lemke, J.H., \& Gisin, G.J. (1991). The Idea of Leisure Repertoire. Journal of Applied Gerontology. 10 (2), 208-223.

Moody, H.R., \& Sasser, J.R. (2015). Aging: Concepts and controversies. London: Sage.

National Institute on Ageing. (2014). Healthy ageing: Lessons learned from the Baltimore Longitudinal Study on Ageing. Available from: www.nia.hih.gov/health/publications/healthy-aging-lessons-baltimorelongitudinal-study-aging/introduction (Retrieved 21st October 2016).

Nimrod, G. (2016). Innovation Theory Revisited: Self-Preservation Innovation versus Self-Reinvention Innovation in later life. Leisure Sciences. 38 (5), 389-401.

Nimrod, G., \& Rotem, A. (2012). An exploration of the innovation theory of successful aging among older tourists. Ageing and Society. 32 (3), 379-404.

Office for National Statistics. (2013). General Lifestyle Survey 2011. Available from:

www.ons.gov.uk/peoplepopulationsandcomunity/personalandhouseholdfinance s/incomeandwealth/compendium/generallifestylesurvey/2013-03-07

(Retrieved 30th September 2016). 
Office for National Statistics. (2015). National Population Projections for the UK, 2014-based. Available from: www.ons.gov.uk/peoplepopulationsand community/populationandmigration/populationprojections/bulletins/nationalp opulationprojections/2015-10-29 (Retrieved 30th September 2016).

Office for National Statistics. (2016). Population Estimates for UK, England and Wales, Scotland and Northern Ireland: mid-2015. Available from: www.ons.gov.ukpeoplepopulationandcommunity/populationandmigration/pop ulationestimates/bulletins/annualmidyearpopulationestimates/mid2015\#ukpopulation-continues-to-age (Retrieved 30 th September 2016).

Oliver, E.J., Hudson, J., \& Thomas, L. (2016). Processes of identity development and behaviour change in later life: exploring self-talk during physical activity uptake. Ageing and Society. 26 (7), 1388-1406.

Organization for Economic Cooperation and Development (nd). www.oecd.org.employment/empageingand employmentpoliciesstatisticsonaverageageofretirement.com (Retrieved 31 ${ }^{\text {st }}$ July 2014).

Robinson, V. (2008). Everyday Masculinities and Extreme Sport: Male Identity and Rock Climbing. Oxford: Berg.

Ryba, T.V., Schinke, R., \& Tenebaum, G. (2010). The Cultural Turn in Sport Psychology. West Virginia: FiT Publishing.

Sparkes, A.C., \& Smith, B. (2014). Qualitative research methods in sport, exercise and health: From process to product. London: Routledge.

Stebbins, R.A. (2002). The Organizational Basis of Leisure Participation: A Motivational Exploration. Pennsylvania: Venture Publishing.

Stebbins, R.A. (2005). Challenging Mountain Nature: Risk, Motive and Lifestyle in Three Hobbyist Sports. Calgary: Detselig.

Stebbins, R.A. (2014). Careers in Serious Leisure: From Dabbler to Devotee in Search of Fulfillment. London: Palgrave Macmillan.

Steptoe, A., Deaton. A., \& Stone, A.A. (2015). Subjective wellbeing, health, and ageing. The Lancet. 385 (9968), 640-648. DOI: http://dx.doi.org/10.1016/S01406736(13)61489-0.

Strachan, S.M., Brawley, L.R., Spink, K., \& Glazebrook, K. (2010). Older adults' physically active identity: Relationships between social cognitions, physical activity and satisfaction with life. Psychology of Sport and Exercise. 11, 114-121. DOI: $10.1016 /$ jpsychsport.2009.09.002

Stuart-Hamilton, I. (2011). An Introduction to Gerontology. Cambridge: Cambridge University Press. 
Tajfel, H. (2010). Instrumentality, identity and social comparison. In Tajfel, H. (Ed). Social identity and intergroup relations. (483-505). London: Cambridge University Press.

Victor, C. (2013). The demography of ageing. In Dannefer, D., \& Phillipson, C. The SAGE handbook of Social Gerontology. (61-74). London: Sage.

Wade, D. (2012). Into the Silence: The Great war, Mallory and the Conquest of Everest. London: Vintage.

Wainwright, R. (2016). Maverick Mountaineer. London: Allen and Unwin.

Westendorp, R.G.J., \& Kirkwood, T.B.L. (2014). In J. Bond., S. Peace., F. DittmannKohli \& G. Westerhof. Ageing in Society. (15-37). London: Sage.

Westerhof, G.J., \& Tulle, E. (2014). In J. Bond., S. Peace., F. Dittmann-Kohli \& G. Westerhof. Ageing in Society. (235-254). London: Sage.

Wood, L., \& Giles-Corti, B. (2008). Is there a place for social capital in the psychology of health and place? Journal of Environmental Psychology. 28 (2), 154163.

Wolinsky, F., Weg, M., Howren, M., Jones, M., \& Dotson, M. (2013). A randomized controlled trial of cognitive training using a visual speed of processing intervention in middle aged and older adults. PLoS. 8 (5). DOI: 10.1371/journal.pone.0061624. 